\title{
PATTERNS OF URBAN DEVELOPMENT IN BUDAPEST AFTER 1989
}

\author{
JÁNOS B. KOCSIS \\ György Ránki Hungarian Chair, Indiana University, 2014-15 \\ Budapest University of Technology and Economics \\ E-mail: kocsisjb@eik.bme.hu
}

\begin{abstract}
This paper will focus on various interrelated, intermingled but often divergent processes and phenomena condensed around the fall of communism in Budapest regarding the spatial structure and development of society and economy. It will demonstrate and analyze major tendencies, such as urban decay, gentrification, suburbanization, emergence of polycentric spatial patterns, effects of globalization, and economic proceedings that have fundamentally altered the position and picture of Budapest and its metropolitan area. It will point out local characteristics as well as the effects of general trends of socio-spatial development on Budapest and its surroundings.
\end{abstract}

Keywords: Budapest, transition, urban decay, urbanization, gentrification, suburbanization, sub-centers, globalization, regeneration, brownfield

\section{Introduction}

The transition to market economy around 1989 was both a turning point in the history of Budapest and the start of a new era. However, continuity of social and economic processes and political and administrative practices were also prevalent. Some changes were totally new in the long history of the city. Budapest had always had a rather centralized municipal system with wide-ranging autonomy before World War II, both financially and politically; whereas Budapest theoretically had an autonomy in a centralized form during socialism it was under strict party control, thus without any real autonomy in any senses. Besides the turmoil caused by the transition to market economy from 1989, the new, two-tier system with the primacy of districts over the capital municipality and with a high level of administrative and political, but with little financial, autonomy posed new challenges to the city. On the other hand, continuity of long-term social, economic, 
demographic and historic factors was fundamental as they exerted their determinative effects on the course of events only with few characteristic and distinct disruptive instances, such as deep crises, that altered their trajectories.

General socio-economic features of the post-communist cities of the East-Central European area have comprehensively been scrutinized (see e.g. Sailer-Fliege, 1999 or Sýkora - Bouzarovski, 2012). The following paper will describe, analyze and summarize the major, deeply nestled socio-economic processes that have determined the present condition of the Hungarian capital. The topic is too wide ranging to be extensively examined here; therefore the main characteristics and phenomena will be emphasized, starting from the historically oldest to the most novel.

\section{Decay in the Inner Areas}

The decay of the inner areas of Budapest started after the 1950s with the nationalization of bourgeois apartments and the tenement sector, concentrated in the core areas, of the city between 1948 and 1952. The introduction of the 'intensive' housing policy measures - that is, increasing the number of the apartments without increasing the floor space - began in the 1950s, and the almost total negligence of the housing stock nationalized while the lack of effective urban regeneration in the forty years to come with concentrated efforts in constructing new housing in the outer areas cumulated in fast deterioration (Antal, 1995, Kocsis, 2009a). Before World War II, although somewhat affected by suburbanization from the 1910s, the middle class areas retained their character, with significant differences between neighborhoods: Józsefváros ( $8^{\text {th }}$ district), the so-called Chicago area in Erzsébetváros ( $7^{\text {th }}$ district) on the lower end, Lipótváros ( $5^{\text {th }}$ district), and the Castle area ( $1^{\text {st }}$ district) on the higher end (Kocsis, 2005 and 2009b, Kovács, 1998:65-6). During the socialist epoch, although the level of segregation significantly decreased and altered in patterns and nature, it was still observable and prevalent despite the official goal of the ideology and 'social engineering'. Segregation became clearly apparent from the end of the 1960s with the introduction of the somewhat 'quasi-market', that is, less strict redistributive, policies with the New Economic Mechanism of 1968. As a consequence, Budapest was far more segregated than other major cities among the socialist countries.

The population started to decrease in the 1960s in the inner districts of Budapest (Table 1). The 'very' core, the $5^{\text {th }}$ district, reached its peak in 1960 with about 66,000 inhabitants whereas in 2005, it had merely about 27,000. Although the drop in population density can also be interpreted as a sign of the strengthening of business, commercial and office activities, as well as rising per capita living space that may well be the case in this district, especially after 1990 (see gen- 
Table 1: Population of the district in inner areas of Pest.

\begin{tabular}{crrrrrrrrr}
\hline $\begin{array}{c}\text { Year / } \\
\text { District }\end{array}$ & 1949 & 1960 & 1970 & 1980 & 1990 & 1995 & 2000 & 2005 & 2011 \\
\hline $5^{\text {th }}$ & 52,782 & 65,867 & 62,684 & 50,128 & 44,113 & 37,087 & 29,720 & 27,273 & 27,113 \\
$6^{\text {th }}$ & 82,359 & 90,448 & 87,937 & 71,205 & 59,812 & 53,811 & 44,746 & 41,914 & 42,832 \\
$7^{\text {th }}$ & 115,495 & 120,052 & 116,078 & 92,350 & 83,115 & 74,638 & 64,159 & 61,337 & 64,414 \\
$8^{\text {th }}$ & 139,673 & 142,783 & 139,000 & 110,532 & 92,847 & 88,455 & 82,099 & 79,845 & 83,882 \\
$9^{\text {th }}$ & 93,575 & 94,717 & 109,810 & 90,095 & 78,382 & 70,821 & 62,977 & 59,791 & 62,988 \\
$13^{\text {th }}$ & 130,551 & 142,137 & 154,984 & 135,889 & 131,812 & 125,806 & 113,210 & 108,942 & 116,207 \\
\hline
\end{tabular}

Source: KSH

trification below), the abrupt fall in population in the doubtless less prestigious 6th district, has been since the 1960s, a clear sign of urban blight. It had almost 143,000 inhabitants in 1960, and then shrank to 110,000 by 1980 and further to about 80,000 by 2005 . The $6^{\text {th }}$ district was the 'least fortunate' as it had lost more than half of its population by 2005. It had over 90,000 inhabitants in 1960 and 42,000 in 2005, and all the other inner districts (namely, the $7^{\text {th }}, 9^{\text {th }}$ and $13^{\text {th }}$ ) also followed the same pattern.

The bulk of the decline took place between 1970 and the mid-1980s, which paralleled the construction of housing estates and later the spread of condominiums and other new forms of residence (Csizmady, 2008:33-50, Kocsis, 2012a) that virtually syphoned the better off from the inner areas and led to a rapid aging of the local societies. The processes, however, forced a deep transformation on the structure of the core as the population decline paralleled a heavy influx of low status population from the countryside, often of Roma background, drawn by the low-skilled jobs in the industrial and service sectors and by the collectivization of agricultural land, concluding with an intense replacement of the populace (Ladányi - Szelényi, 1998, Csanádi - Ladányi, 1992). Such changes did not uniformly affect the inner areas. Within the general urban decay, blight affected the outer areas of the $6^{\text {th }}$ and $8^{\text {th }}$ districts (especially the latter) and large areas on both sides of the Grand Boulevard (Nagykörút) in the $9^{\text {th }}$ district (Csanádi et al., 2010a: Maps M1.1 and M1.2). The problems were intensified by the actual workings of socialist housing policies, which, despite their theoretical goals, disfavored the worse off (Kocsis, 2004:70-2). Decay usually leads to an increase in crime-related activities, including heavy and visible presence of prostitution. This was especially prevalent around Mátyás and Rákóczi Squares in the $8^{\text {th }}$ district and from the early 1990s was accompanied by drug-related activities.

The influx of the unskilled and low-skilled lower status population crested a new wave in the 1980s with the deindustrialization of small towns and villages whereas tertiary economic activities became predominant in Budapest, creating 
a notable demand for labor. The almost total collapse of economic, especially industrial activities in large regions in the country, especially in the north-east, and the economic austerities and crises in the early 1990s, also generated a vast stream of migration to the capital. However, the breakdown of capital from the late 1980s caused such low-skilled workers to face more and more difficulties in finding permanent and better paid employment.

The privatization of the council housing stock, sporadically from the 1980s and speeding up around 1989 (even made compulsory by the 1993 Housing Law), also contributed to the deepening blight. During the process, the ratio of public tenement stock shrank from 50 per cent to six, with the sale of 350,000 units (Kovács - Tosics, 2014:47, Kocsis, 2004:77-80). The law gave the right to buy to sitting tenants in apartments of appropriate standard, excluding ones officially entitled to be protected as historic buildings or in areas with accepted redevelopment plans. The latter two restrictions did not have significant effects on urban poverty, but the former resulted in a municipal tenement stock made up almost exclusively of decaying substandard homes that the municipalities had no revenue to renew. As a consequence, those who could sustain the municipal tenement sector left and only the poor stayed behind, forcing the municipalities to further privatize the remaining stock.

The virtual lack of rehabilitation during the socialist epoch in the 1990s deepened problems. In 1989, the total cost of deferred maintenance in Budapest was estimated to be as much as HUF 200 billion, or USD 3.3 billion, about 10 per cent of the total annual GDP of the country at that time (Kocsis, 2004:74). The problem was most severe in the inner areas where the majority of the housing stock was built before World War I. There were sporadic instances of rehabilitation in the 1970s and 1980s, extending one or two blocks, or even only to individual buildings within blocks, in Erzsébetváros, with only one, significant although failed large-scale attempt in Józsefváros in the late 1970s with the construction of Józsefvárosi Housing Estate (Csanádi et al., 2010a:74-6). In the major part of the area, no effective and systematic regeneration programs have been carried out as most renovations have been the result of isolated efforts of investors or condominiums; although the latter could use funds from the municipality of Budapest for that reason from 1997 on. Two examples stand out: Ferencváros and Józsefváros, $9^{\text {th }}$ and $8^{\text {th }}$ districts, respectively. Since the 1960s, Ferencváros struggled with attempts at regeneration but without political backing such efforts were fruitless before 1989. As a consequence, the existence of elaborate plans and regulations that allowed municipalities with accepted rehabilitation plans not to privatize their tenements stock (1993 Housing Law, see above), crucially eased the realization of already existing and widely accepted intents. Although claimed to be 'social regeneration', that is, an attempt to keep the most people in an area, related organizations facilitated the out-migration of the 'less desired', 
lower strata. Mass-scale new developments with significant regeneration of existing buildings - parallel to the demolition of a great deal of them - characterize the processes in the district that have attracted momentous investments in the area where in the inner area, between the two boulevards, entertainment and catering dominate, while on the outer side of the Grand Boulevard, housing developments dominate. This has led to substantial social consequences from 1998 (see gentrification below). Józsefváros, undoubtedly the least prestigious inner district, chose a different path. The construction of the Józsefvárosi Housing Estate (1979-1980) was a long-planned effort to better the poor housing and social conditions, but the outcome proved a fiasco, as this housing estate soon became one of the most disreputable in the city. After 1990, the new municipality chose three different strategies for the district that started to bear fruit only after 2000. In the inner, most promising areas, it facilitated private initiatives with supportive regulations and regeneration of public spaces (the Mikszáth Square area). The area with the worst housing conditions but with the most promising potential, along Üllöi út, was renamed Corvin Quarter. With the replacement of the population huge areas were demolished that had been some of the largest urban development projects in Europe. The infamous, prostitution and crime hit area around Mátyás Square was rebranded Magdolna Quarter and has become one of the largest examples of social regeneration in Europe with reconstruction and renovation of the existing housing stock and public areas, social, neighborhood and capacity building programs, and with the deliberate intent to keep the area affordable and livable for its existing populace (op. cit. 76-131). Although the more the signs of upgrading multiply, the more the social changes are becoming apparent.

A feature unique in Central Europe is that a significant size of the lower, or underclass, urban population is made up of Gypsy population, giving an ethnic attribute to the segregation (Csanádi - Ladányi, 1992, Kovács, 1998, Ladányi Szelényi, 1998). The emergence of ghetto-like urban ethic enclaves intensified segregation and blight, especially in the $7^{\text {th }}$ and $8^{\text {th }}$ districts, and made the situation resemble those in some American and Western European cities. However, it has to be noted that ethnic minorities never made up more than half of the population in those districts.

The mass emergence of homelessness was associated to the transition to market economy, and was a result of economic crisis. During socialism, homelessness was regarded as a legal offence and the sudden appearance of the homeless and beggars was a shock to the general populace. Multiple reasons stood behind the sudden massive appearance of homelessness. Vagrancy, that had been against the law, became decriminalized, the living standards of the population fell, especially in the countryside, and the impoverished people flocked to the urban centers in hope of finding livelihood. The cheap workers' hostels that accommodated the weekly or monthly commuters from the countryside were shut down. Moreo- 
ver, the shrinkage of capacities of the social and mental care systems, especially during the time of austerity, added to the problem as the less severe patients were sent away. Youth leaving from the state foster homes and a large ratio of divorcees also ended up on the streets without sufficient funds to rent or buy accommodation. The relative number of affected people in Budapest was high, estimated between 8,000-15,000, where 80 per cent arrived from the provinces. Most of these people are 'hidden' and the number of those who are virtually present on the streets - in subways, underpasses, sidewalks, shop windows, and in crowded areas - is estimated well under a thousand (Kocsis, 2004:81-2).

The disappearance of core function areas and ghettoization are well known and intensely studied in the United States and England, where they are less severely acute in Western Europe. In this regard, Budapest rather followed the Anglo-Saxon model and by the mid-1990s, the central areas had virtually lost most of their productive functions, which were essential for economic and social sustainability and maintenance. The upper and middle strata no longer regarded them as a desirable place to live and, with the collapse of the economy, most of the cultural functions disappeared, while a wide range of economic activities moved to other, especially outer, green-field areas; such as retail, commerce, entertaining, and catering. Offices and headquarters of small and bigger firms and companies also relocated. There was more than a decade in central Budapest without any notable department store or shopping street.

The situation looked so severe in the second half of the 1990s that renowned social scientists projected the 'Americanization' of Budapest's inner areas where strict core areas would be dominated by commercial and business functions and the transitional zone would face further social deterioration as a consequence of middle class flight while upper strata would be driven away by soaring crime rates, growing ethnic segregation, and ghettoization (Ladányi - Szelényi, 1998).

\section{Brownfield Areas}

As central areas are the forefront of observation, areas in the adjacent ring were given far less attention, notwithstanding the fact that more serious social and economic deterioration may have hit them.

The affected areas surround the core in a half-circle, especially along the main artilleries and the River Danube. This is mostly in the northern, eastern and southern areas and consists of derelict, un- or underused industrial areas, workers' colonies, originally attached to some factories, institutions requiring large lots, such as hospitals, cemeteries, etc., some agricultural lands, and wastelands. The total area classified as brownfield takes up approximately 68 square kilometers, 
that is, 13 per cent of the total territory of Budapest - or about 30 per cent of the total urbanized areas (Kukely et al., 2006:61). Characteristic industrial activities were heavy industries, breweries, slaughterhouses, chemical, medical, and electronic plants, brick factories, power stations, and food factories. In addition, warehouses, other storage facilities, logistical and necessary infrastructural zones also formed parts, with some particular areas. Historically, the bulk of this sector lay in the void between the densely built core of Budapest and the city limits towards the predominantly residential suburbs. Additional axes to this crescent were added along the main traffic artilleries and the Danube, both towards the city and outwards, and some segregated plants were also present in Buda along the outer ring road.

With the focus on industrial developments concentrated in this sector, the socialist régime did not alter its fundamental characteristics, despite the annex of the related suburbs to Budapest in 1950. There were some unsuccessful efforts to lessen the weight of Budapest as the sole big industrial center of Hungary in the 1960s and 1970s (Kocsis, 2009b).

The main causes of the problems stem from the 1970s with the shrinkage of the industrial activities of the capital. The situation turned severe during the transition to market economy around 1989 when especially the heavy industries were severely affected, but did not fully disappear. The industrial activities in Budapest started growing again after 1994, employing about 115,000 people in 2006 (Kukely et al., 2006:60), on both traditional and new greenfield sites too. The shift from the former to the latter created, and still creates tension both in the brownfield sector and in the suburbs, as the new, post-Foridist economic, industrial activities, integrated in a globalized economy, require large areas. Such sites are most easily and cheaply to be found in greenfield areas and not in the often polluted brownfields. The ratio of traditional industrial areas, nonetheless, are still of great significance and in such territories, 24 per cent of all employed worked in 2006 (ibid.).

The present state of the brownfield areas is far from homogeneous. Those in favorable positions, such as the segregated plants in central Buda and the areas along main axes, especially in the north of Pest, and recently in Buda, were quickly renovated and turned into shopping malls, residential, and office areas. The development is best perceived in Pest along Váci út with its dozens of office towers, which area used to be dominated by factories and warehouses. In Buda, developments in the stripe along Budafoki út in the $11^{\text {th }}$ district in the south, in sites around the Gas Factory in the $3^{\text {rd }}$ in the north, have recently gained significant momentum. Adjacent to them, and a bit more hidden, but still easily accessible, areas serve as fairly cheap sites for various economic activities, mostly related to IT and other related fields. Such areas were originally mixed in character with residential plots for working class families, small-scale factories, and other 
industrial units, with a huge ratio of empty or underdeveloped patches. Thus, besides economic functions, such areas have also been prime targets for residential development, especially the $13^{\text {th }}$ district. To a much lesser extent, similar tendencies may be observed in the $9^{\text {th }}$ district, along Soroksári út. The causes of differences lie partly in the dissimilar socio-economic status of the surrounding communities. The aforesaid stripe in the $13^{\text {th }}$ district is easily reachable from the prestigious north Buda while the southeastern areas of the city, both in the core and in the suburbs, are less reputable. In addition, the former has an advantageous traffic connection with the M3 subway line whereas the latter is less well integrated in the system. Worth mentioning is that public transport is still the main form of traffic for most in Budapest and thus accessibility, especially via subway, or major tram lines, is of primary significance for such developments.

Some large-scale sites, predominantly in Csepel and Kőbánya in the south and south-east of the city, have retained their industrial character, either in their 'original', redeveloped form, such as the pharmaceutical plants in Köbánya (e.g. Richter Gedeon) or on the 'ruins' of previous sites, like the huge site of Csepel Iron and Steel Works on Csepel Island (which during its heyday employed 20,000 workers and now houses a myriad of small and medium enterprises that employ 10,000 people). Other huge sites in less favorable positions have faced a different fate, like the huge breweries in Kőbánya, which have become empty (as new technologies require less space), and they are still awaiting their new functions. These sites, with the size of tens of thousands of square meters, often have beautiful industrial buildings and cellars of significant architectural value (Budapest..., 2014:17).

Yards and other rail infrastructure, which belong to the Hungarian State Railway (MÁV), form a distinct part of the brownfield sector. They cover extensive territories that also act as long edges separating large neighborhoods and districts (op. cit., 27). Moreover, colonies built for workers of the MÁV are also set in such areas, apart from the rest of the city by the aforesaid edges, and are now often in a blighted social and physical state, causing grave social problems. Acting itself as a state within a state, the attitude of MÁV, rooted in its socialist past, is one of the main sources of the problem as it is the least susceptible to the value of the land and to its location and thus uses it prodigally, well beyond its needs and economic necessity. Potentially, two large yards, one in the $9^{\text {th }}$ (Ferencvárosi) and $2^{\text {nd }}$ between the $13^{\text {th }}$ and $2^{\text {nd }}$ districts on one side and $14^{\text {th }}$ and $15^{\text {th }}$ on the other (Rákosrendezö), could be in the future of some large-scale development while some, many smaller and now defunct ones could house important functions and complexes, as it has already happened in some instances, such as the site of the National Theater and the surrounding area that used to be a freight terminal. Extensive track systems beyond existing railway stations in the core area also have huge potential, as the partial development of the tracks of Western Railway 
Station (Nyugati pályaudvar) and related prospective wide-reaching plans have shown (op. cit., 17).

Most problematic are the derelict plants, abandoned warehouses, mines, and other dilapidated territories in the least favorable position, especially farther from the core in the east and the south of the city, where also isolated, blighted, residential communities are scattered often in a polluted environment. Fractured ownership structure, high costs, inevitable environmental remediation, and necessary infrastructural developments were the main causes of the lack of redevelopment efforts, but conflicts and tensions in the two-tier administrative system between the districts and the capital municipality, and between Budapest and the suburbs also played an important role. Severe economic problems, especially since 2006, further thwarted the renewal. Last but not least, lack of possible viable economic or social functions or feasible, realistic new ideas have all stymied their successful redevelopment and renewal. However, small steps have been taken but more fundamental, successful expansion requires new, innovative schemes and probably some substantial economic development.

Existing forms of usage often forestall the potential of future developments. Logistics heavily present in the area generates much freight traffic resulting in noise, dust and pollution (op. cit., 21).

The brownfield sector further has quite a lot of potentials because it contains vast agricultural and undeveloped land that would enable notable recreational, sports and residential development, if it were better connected to the abutting areas and the whole city and remediated from waste and pollution. Thus, it could ease the pressure on suburban areas, both in economic and residential terms.

\section{Suburbanization and urban sprawl}

Suburbanization and urban sprawl were by far not new phenomena that emerged in the 1980s. The momentum of population growth gradually shifted from the core areas to the outer, then outlying areas of the city during the last decades of the 19th century. Large, predominantly working-class settlements sprang up around the city borders, especially east of the River Danube. From the early 1910s, the significant groups of the higher social strata started migrating primarily to the hilly areas of outer Buda, following the examples of the haute bourgeoisie and the élite some decades earlier. The latter phenomenon reflected the changes in lifestyle and priorities (Kocsis, 2005). Suburbanization, that is, the outward migration of the middle and higher strata to primarily residential areas, continued into the interwar period, resulting in the rapid development of the outer, previously uninhabited outer areas of the Buda districts. This created a large, rather homogeneous high prestige sector in the western part of the city. The migration 
from the countryside to the outskirts, dominated by the working and lower strata continued and was especially intense during times of economic austerity (Kocsis, 2009b:45-59).

The overall majority of areas, then considered an agglomeration belt, was annexed to Budapest in 1950 and the new borderline was much more than a simple administrative issue as it strictly divided the capital from the surrounding areas, mostly deemed not to be developed in the forty years to come. Migrants arriving from the countryside, a pressure arising from the collectivization of land and industrialization could not find accommodation in sufficient number within the borders of Budapest and thus were forced to move to the villages neighboring Budapest. But, as housing construction sped up, especially from the 1960s, their majority moved to Budapest, chiefly to the new housing estates (Kocsis, 2012a). As a result, the social composition of the agglomeration belt was rather homogeneous and lower middle strata dominated. The overall characters were rural.

Impetus towards suburbanization and urban sprawl, although somewhat lessened but not diminished in the socialist period, due to the rigid nature of the administrative border, those willing to migrate to the less dense areas had to find suitable parcels or other means within the city limits. In this way both those who wanted to move from the dense central areas and those who migrated from the countryside to the capital and preferred the small-town like environment moved to the outer districts. These tendencies, although similar in origin to those in the West, took on twisted manifestations due to the constraints of socialist regulations and planning systems. As the state of the inner areas degraded from the 1950s, the housing estates, constructed first at the periphery of the core then gradually moving outward, became the prime target of the better off in the inner areas, until the prestige of the housing estates drastically fell in the early 1970s. Consequently, condominiums, small-scale estates, and semi-detached and detached houses, in the prestigious, especially Buda, areas came to be the prime targets of such social strata. For the less wealthy, large-scale family housing areas in the outer, underdeveloped, mostly Pest, districts, were feasible options from the 1970s (Kocsis, 2009a and 2012a). To satisfy the still existing further demand for greener and sparser living conditions and befitting the underdeveloped infrastructure and poor services, temporal and more distant means appeared in abundance. Secondary homes and weekend cottages of the well-to-do sprang up in huge numbers close to rivers and lakes, especially along the Danube and around Lake Balaton, whereas the less wealthy bought garden-plots, especially around Budapest, in the future agglomeration belt in large patches beyond, sometimes rather far from, the inhabited areas. This was not by far an utterly novel phenomenon, similar processes, although much less intense and affecting smaller areas, appeared in the then outer, now inner, agglomeration ring in the interwar period (Csanádi et al., 2010a:274-5). 
Table 2: Population of the Budapest Agglomeration.

\begin{tabular}{lrrrrr}
\hline Year / Region & \multicolumn{1}{c}{1990} & \multicolumn{1}{c}{1995} & \multicolumn{1}{c}{2001} & \multicolumn{1}{c}{2005} & \multicolumn{1}{c}{2011} \\
\hline Budapest Proper & $2,016,000$ & $1,906,000$ & $1,775,000$ & $1,680,000$ & $1,729,040$ \\
Agglomeration Belt & 567,000 & 599,000 & 672,000 & 724,000 & 805,848 \\
Total Agglomeration & $2,583,000$ & $2,505,000$ & $2,447,000$ & $2,404,000$ & $2,534,888$ \\
\hline
\end{tabular}

Source: KSH

The situation changed rapidly during the second half of the 1980s, as people started moving to settlements abutting Budapest for permanent residence (Table 2). Reasons for the 'discovery' of the area are manifold, including the readjustment to market economy, privatization of previously nationalized agricultural land, the large-scale arrival of the foreign investments, the proliferation of inequalities, collapse of socialist housing and regional policies, decentralization of the municipalities, deterioration of the prestige of the housing estates, privatization of the council housing sector, further decay and rise of crime level in the inner areas, increased residential mobility, and last but not least, the significant changes in housing ideals, mostly resulting from the penetration of cultural patterns from the West. From the early 1900s, such processes were additionally accelerated by the transformation of the municipal system and the rapid catchingup and development of these suburban settlements in terms of amenities, infrastructure and services. In the process, first the temporal homes were enlarged and turned into permanent usage, then, traditional 'peasant' homes were modernized. Later, gradually new constructions appeared, first within the traditional residential, then from the second half of the 1990s, green-field, areas, sometimes rather far from any old villages and towns and suburbanization affected more and more distant settlements, especially along the main traffic artilleries, with attractive, green and quiet environments. Besides the archetypical suburban genres, like detached and semi-detached houses and gated communities, denser forms also appeared, almost mimicking the smaller housing estates of the 1980s. Migrants included the better-off, moving especially to the inner western and northern part of the agglomeration belt, commuting back to the central areas, and the poorer strata, which fled from the increasing cost of living and property prices of the city proper and moved to the cheaper, outer, especially southern and eastern sectors, often with loosened connections to the city. Such patterns of social segregation in the agglomeration belt, in fact, reflected the existing structures within the city limits. The social sectors fundamentally grew beyond the boundaries, changing the previously homogeneous social characteristics of the settlements and also triggering rapid urbanization in the way of life. Large prosperous areas formed in the western and northern sectors of the agglomeration belt while the other sections have remained predominantly lower class, without large-scale deprived 
areas. Within such large sectors of seemingly homogeneous character, however, significant levels of heterogeneity can be found on micro-levels, with pockets of poverty even within the richest settlements and pockets of wealth within generally poor areas - a phenomenon well known in Budapest (Csanádi - Ladányi, 1992, Kocsis, 2009b:22-25, Kocsis, 2012b).

The social character of a large part of the settlements, especially those of the emerging sub-centers (e.g. Budaörs, Törökbálint) and some 'intellectual havens' (e.g. Budakeszi, Nagykovácsi) drastically changed due to the influx of highly educated, more affluent and younger people, often creating tensions within the local community and politics (Kocsis, 2015, Kovács - Tosics, 2014, Szabó et al., 2011, KSH, 2013:12-16, KSH, 2014:9).

In the beginning, many municipalities made strong attempts at controlling and limiting the influx while others warmly welcomed the migrants with new parcels and roads. A more complex attitude evolved from the early 2000s when the high costs of infrastructural developments, necessitated by migrants, and the social consequences were realized. The pace of influx slowed down parallel to increasing suburbanization within the official boundaries of the city, in the outer districts, and to the developments in the inner areas Csanádi et al. 2010a:229-99, Csanádi - Csizmady, 2002, Kocsis, 2012).

The stress in more 'advantageous' settlements shifted to economic development as a new phase of urban sprawl took shape: polycentric urban development, where the most advantageous and developed towns have become sub-centers in the transforming and evolving metropolitan area of Budapest. Economic activities began to flow to towns from the end of the 1990s. First those ones abutting Budapest with favorable geographic positions were affected, mainly along national highways (e.g. Budaörs, Fót, Gyál). Then other, more distant territories gradually joined along the main artilleries and the M0 beltway, constructed during this period (e.g. Gödöllö, Törökbálint, Biatorbágy, Szigetszentmiklós). Such economic functions include service, office, industrial, commercial, and logistic activities. The area in the southwestern agglomeration belt, around the highway triangle formed by M0-M1-M7 has become an important economic pole with characteristics that closely resemble those of edge cities in the United States and Western Europe. These sub-centers often offer employment in larger numbers than they could satisfy and thus have become targets for commuters. Patterns of commuting changed and the most educated still commute to the core areas as the most highly paid jobs are there whereas middle strata commute to these emerging sub-centers in increasing numbers, the lower strata either commute to the city or try and find employment in the vicinity (Kocsis, 2012b, Kovács - Tosics, 2014:41-45).

By the mid-2000s, urban sprawl reached areas beyond the agglomeration belt and gradually connected settlements in a single network along the main artiller- 
ies in a 60-80 kilometer radius circle, forming a single, polycentric, metropolitan area housing three million people (almost one third of the country), utilizing on, and synthesizing the synergies of, integrated economic, innovative and social clusters dispersed, but also within the proximity, in the metropolitan region. Such developments are in line with the spatial developments of American and Western European urban development in the last thirty years, although the status of the network is less evolved with numerous factors hindering its development while large, island-like unaffected areas are situated within the area (Csanádi et al., 2010a:231-5, Szabó et al., 2011).

The rate of suburbanization decreased around 2008 (KSH, 2014:4) but it does not sign the end of suburbanization, as many projected (Kovács - Tosics, 2014:41). A more balanced relation between the suburbs and the core areas of the city comes rather into being as consequence of developments in the core and gentrification, where the migration to the suburbs, within or without the administrative borders of Budapest, tends towards equilibrium with the migration from the suburbs and from other areas to the inner areas (Table 2, KSH, 2013, Kocsis, 2012b).

\section{Gentrification}

After the glorious days before World War II and a slow but steady deterioration and decline during socialism, the future of the inner areas seemed doomed in the middle of the 1990s, after the deep and long economic crisis resulting from the transition to market economy. Urban decay appeared inevitable, especially with the acceleration of suburbanization and that fact the inner areas became segregated and blighted (e.g. Kovács et al., 2013:23). Quite unexpectedly, however, the population of the inner areas started stabilizing at the turn of the millennium, despite the ongoing suburbanization, and the population of Budapest proper commenced to increase after 2005, which included inner areas (Tables 1 and 2) while the characteristics of the streets and activities changed profoundly, turning quiet, aging and poor neighborhoods into vivid, colorful ones attracting well-to-do young people. There had been earlier centralized attempts at luring 'posh' people, high-end shops and sumptuous, elegant activities in the area but they failed because of the lack of demand. The situation has, however, altered to a significant degree since 2010 as new socio-economic phenomena have taken shape.

Only sporadic examples of rehabilitation were carried out before 1989 and the situation changed slowly afterwards with the sole large-scale rehabilitation project in the $9^{\text {th }}$ district in an area which had been designated to regeneration well in the 1980s and thus had not been privatized. Later on, two major examples in the $8^{\text {th }}$ district joined in, the Corvin and the Magdolna Quarters in the 2000s. 
The last intended to maintain the original population of the neighborhood where the former two, explicitly or covertly, targeted a fundamental change in population by attracting younger, more affluent and better off strata through the demolition of a large ratio of the existing housing stock and through the displacement of the original, poor, population. In 2006, 70 per cent of the population in the rehabilitation area in the $9^{\text {th }}$ district and 44 per cent in the $8^{\text {th }}$ district had moved to the area in the previous five years (Kovács et al., 2013:32). In other areas, in spite of the magnificent, but failed, attempts such as Madách Promenade (e.g. Kovács, 1998:76-7), similar processes started in an unorganized way from the early 2000s when investors first bought up empty sites, then existing buildings and a fastpaced demolition of the core areas began. In such cases, the ratio of displacement was rather low. The investors were mostly Spanish and Israeli companies that constructed expensive and relatively small flats in the area by the thousand before the crisis of 2008. In fact, more institutionalized ways of rehabilitation elsewhere had lacked both the legal and planning framework as well as the necessary financial resources in the 1990s (Kovács et al., 2013:26).

In the beginning, consequently, centralized, municipal programs played only a secondary role in triggering inner city regeneration in Budapest. Changes on the demand side, that is, appearance of new social and economic functions and related strata were the key factors behind the present transformation. As a result of the sporadic investments and increasing demand, the prices later grew by 40 per cent between 2002 and 2008 in the inner areas of the $7^{\text {th }}$ district and by about 120 per cent in the two above-mentioned quarters in the $8^{\text {th }}$ district (Csanádi et al., 2010b:120-1). Thus the specialized rehabilitation organizations and private investors used later the value gap to turn their investments profitable and because of the huge opportunities and the sheer size of possible revenues they could well convince local municipalities to support their activities in one way or another (Kovács et al., 2013:25).

Gentrification is an influx of affluent newcomers and second-home owners to the poorer inner urban areas that drives up housing prices, introduces new services, regenerates the neighborhood, and transforms local communities (Hutchinson, 2010:305, Tomay, 2007:122). As a startling surprise for scholars at its appearance around 1990, it has been in the forefront of urban studies in the recent decades worldwide. The causes of this phenomenon have been theoretically and empirically studied with various, sometimes contradicting, outcomes (see e.g. Hutchinson, 2010: 306-8). Fundamentally, two major processes contribute: economic changes labeled under the umbrella of globalization and recent transformations in lifestyle and society.

Post-Fordist economies rely more and more on information and effective decision-making that enhance the role of central places, namely cities, where physical proximity, cardinal despite information technology, ensures the most advanta- 
geous position in the network. Thus centers of decision-making, like company headquarters, gradually moved first to the most important cities from the late 1980s and then to other major ones about a decade later that arrived in EastCentral Europe around 2000. The arrival of well-paid professionals (also known as young urban professionals, or yuppies) has brought about widespread development of accompanying service infrastructure, both hard such as traffic facilities, constructions, and soft such as restaurants, specialty shops and a web of auxiliary services. Such processes deeply altered the socio-economic picture of the core areas. Although observable, such processes are secondary in the present state of Budapest, due to the relative weakness of economy and lack of massive decisionmaking centers.

More important are the consequences of the social transformation resulting from complex, manifold, partially intertwined processes. After the epoch of modernism a significant portion of people turned from the 1970s to more conservative values, protecting something that seemed to be lost, like environment, monuments and past, and idyllic lifestyles, hence, they started to value the historical, urban environment, and rediscovered the romantic core areas. Artists also discovered the potential in the then cheap, well-serviced neighborhoods. In addition, some offspring of the middle class suburbanites started to get bored and isolated in the homogeneous outskirts and began to move back to the more stimulating, eventful, lively inner city. Families who found the suburban life too expensive, also joined them, especially after the crisis that started in 2006 in Hungary. Due to widening higher education, student number has multiplied, also adding to those preferring life in the center. The rising number of international students also fostered studentification. Delayed childbearing and family formation age, and new, non-traditional forms of cohabitation - the phenomenon of the so-called second demographic transition - and fragmentation of lifestyles and housing preferences have further increased the number of middle class people looking for accommodation and life there. Moreover, many young urban middle class families with children have opted for staying in central areas instead of moving to the suburbs - the so-called young urban professional parents, or 'yupps'. To this roughly permanent demand more temporal forms, such as the new types of tourists, like backpackers, hen and staggers, seekers of cheap alcohol and thrills, have been added. Naturally, different strata settle in different places: families, for instance, prefer quieter, more homogeneous, secure neighborhoods a bit farther from the core. These phenomena have gradually transformed the core of Budapest since the early 2000s, and as demand for the inner city has grown, the investors have also discovered the area as it is capable of yielding more profit due to the lower prices than suburban areas. As a consequence, the regeneration processes have been 'spontaneous' in a major part of inner Budapest, resulting from social and business pressure, rather than from some systematical, coherent, planned effort. 
The results, from one point of view, are tremendous: over 40 per cent of the buildings had been renewed in the inner city in 2005 (Kovács et al., 2013:28) without any significant central initiative; whereas prestigious buildings even in prime locations are still wearing bullet holes from either World War II or the Revolution of 1956 and have not been renovated since their construction over one hundred years ago. The situation is obviously worse in poorer areas.

Statistics and extensive analyses demonstrated the effects of gentrification and studentification on neighborhoods in the inner $7^{\text {th }}, 8^{\text {th }}$ and $9^{\text {th }}$ districts (Csanádi et al., 2010a:82-131, Csanádi et al., 2010b:122-4, Kovács et al., 2013:32-34, Tomay, 2007), and also the differences compared to other gentrified Western cities. First, the local demand is weaker because of the traditional lack of capital and feeble middle strata. Second, urban decay still prevails in many neighborhoods parallel to the gentrified ones as many lower status people cannot sell their flats in their present state and thus are entrapped in their low-quality homes. Third, investors have produced housing for foreign (especially Spanish, British, and Irish) second-home buyers who buy their flats as investments, thus large blocks are virtually empty year around. Last, but not least, the power of foreign 'fun-seekers' is relatively large and thus the industry that serves them has deeper ramifications and imprint.

A somewhat novel and unexpected experience in Budapest is the mass-scale appearance of Western European and American partygoers and requires some further analysis. This is not by far a new phenomenon in East-Central Europe as Prague faced their invasion in the early 1990s and some other Baltic towns joined in in the 2000s. What is fundamentally different is the way in which it joined. In the aforesaid places the inner core was first physically renovated and then it was discovered. In case of Budapest, young local entrepreneurs, artists, students and others started to culturally regenerate and gentrify some cheap central neighborhoods, first in the $8^{\text {th }}$ and $9^{\text {th }}$, then in the $6^{\text {th }}$ and $7^{\text {th }}$ districts, and occupied them in various, exceptional, unconventional forms (most notably, the 'ruin' bars and venues) from the late 1990s, often in illegal forms with strong civic backing and influential social networks (Lugosi et al., 2010). With this elaborated web of venues and 'know-how' of hospitality and entrepreneurship, after the crisis of 2006-10 that had elementally affected the local purchasing power, was Budapest 'discovered' by the 'hordes' of foreign youths from 2011, which led to the commercialization, mass-scale restructuring and industrialization of the pub- and cultural scene. Somewhat ironically, the breakdown of the Hungarian national airline, Malév, in 2012, played a positive part in this process as it opened up the airport of Budapest to the cheap flight providers.

Gentrification poses different threats in Budapest than in other western cities. Segregation and social polarization present mostly similar dangers but because of the fundamental dissimilarities in ownership structure,, that is, the low level 
of tenants, related inhabitants are not hurt by the rent increase- on the contrary, those who can sell their property may well gain from the soaring prices. Those living in substandard housing are, on the other hand, badly affected: those in their own homes may find it hard to sell the property, others living in the still existing council housing sector, that is typically in very bad shape, pay low rents but may hope in vain for a betterment of their housing situation. In centrally renovated buildings, such residents may well be displaced to other, less prestigious neighborhoods, often in outer districts, thus transposing the situation elsewhere, especially if carried out in mass scale, as it happened with residents of the $8^{\text {th }}$ district transferred to a housing estate in Csepel (21 ${ }^{\text {st }}$ district).

\section{Conclusions}

Budapest was in a privileged position before 1990 as it was the biggest and most important city in the country. It was wealthier compared to other socialist cities and bigger than any other in a huge radius. Its potential seemed exceptional. Vienna had traditionally been on the horizon as a rival but it was a well-known one and Budapest had hoped to occupy the familiar situation with a small primacy of the former. These comfortable prospects made Budapest lazy and unprepared for the challenges of globalized Europe with its dozens of competing cities, conurbations, and huge metropolitan areas where it found itself unexpectedly in the 1990s. Problems and tasks it has been facing are not unique at all but are rooted in local historical, political and social characteristics that distinguish it from other East Central European major cities; so much so that the reason for a general East Central European urbanization model was seriously questioned among scholars. Although the ratio of common and special features may be debated, it is undeniable that Budapest and its unique urbanization require particular attention.

\section{References}

Antal, Andrea. 1995. Egymillió lakás. História, 16 (9-10), 47-48.

Budapest Főváros Önkormányzata. 2014. Barnamezős területek fejlesztése tematikus fejlesztési program. Budapest: Budapest Főváros Önkormányzata. Available at: Budapest Portál http:// budapest.hu/Documents/TFP/Barnamezős\%20területek\%20fejlesztése\%20Tematikus\%20Fejlesztési\%20Program.pdf [Accessed 20 March 2015].

Csanádi, G. and Csizmady, A. 2002. Szuburbanizáció és társadalom. Tér és társadalom, 16 (3), 27-55.

Csanádi, G., Csizmady, A., Kocsis, J. B., Köszeghy, L. and Tomay, K. 2010a. Város Tervezö Társadalom. Budapest: Sík Kiadó.

Csanádi, G., Csizmady, A. and Olt, G. 2010b. Recent Trends in Urban Renewal in Budapest. Urban Challenge, 21 (1), 117-125. 
Csanádi, G. and Ladányi, J. 1992. Budapest térbeni-társadalmi szerkezetének változásai. Budapest: Akadémiai Kiadó.

Csizmady, Adrienne. 2008. A lakóteleptől a lakóparkig. Budapest: Új Mandátum Könyvkiadó.

Hutchinson, Ray ed. 2010. Encyclopedia of Urban Studies. Los Angeles: Sage.

Kocsis, János B. 2004. The Housing Poor in Budapest, Hungary. In James Fearn, ed., 2004. Too poor to move, too poor to stay. Budapest: OSI, 67-95.

Kocsis, János B. 2005. A kertváros a századforduló Budapestjén: A Bírák és Ügyészek Telepe. In Farkas, J., S. Nagy, K., ed. 2005. Társadalmi térben. Budapest: BME, 223-228.

Kocsis, János B. 2009a. Lakáspolitika Budapesten, 1950-1959. Múltunk, 2009 (3), 83-122

Kocsis, János B. 2009b. Városfejlesztés és városfejlődés Budapesten, 1930-1985. Budapest: Gondolat.

Kocsis, János B. 2012a. Lakáspolitika Budapesten 1960-1975 között: A szocialista lakáspolitika „aranykora”. Múltunk, 2012 (1), 160-206.

Kocsis, János B. 2012b. The Socio-Economic Transformation of Suburbs in a Central European Metropolitan Area: Arrival of the Affluent Strata and Polycentric Urban Development in Budapest Suburbs. In 7th International Conference on Interdisciplinary Social Sciences. Barcelona, Spain, 2012.06.25-2012.06.28. Conference paper.

Kocsis, János B. 2015. A nagyváros útjában. In Keszei, András-Bögre, Zsuzsanna (eds) 2015. Hely, identitás, emlékezet. Budapest: L’Harmattan, 163-184.

Kovács, Z. and Tosics, I. 2014. Urban Sprawl on the Danube. In L. Sýkora-K. Stanilov, eds. 2014. Confronting Suburbanization. Urban Decentralization in Postsocialist Central and Eastern Europe. Chichester: Wiley Blackwell, 33-64.

Kovács, Z. 1998. Ghettoization or Gentrification? Post-Socialist Scenarios for Budapest. Netherland Journal of Housing and the Built Environment, 13 (1), 63-81.

Kovács, Z., Wiessner, R. and Zischner, R. 2013. Urban Renewal in the Inner City of Budapest: Gentrification from a Post-socialist Perspective. Urban Studies, 50 (1), 22-38.

Központi Statisztikai Hivatal (KSH). 2013. Közlemények a budapesti agglomerációból 16. Budapest: Központi Statisztikai Hivatal.

Központi Statisztikai Hivatal (KSH). 2014. Migráció és lakáspiac a budapesti agglomerációban. Budapest: Központi Statisztikai Hivatal.

Kukely, G., Barta, G., Beluszky, P. and Győri, R. 2006. Barnamezős területek rehabilitációja Budapesten. Tér és Társadalom, 20 (1), 57-71.

Ladányi, J. and Szelényi, I. 1998. Szuburbanizáció és gettósodás. In Kovalcsik, Katalin, ed., 1998. Tanulmányok a cigányság társadalmi helyzete és kulturája köréböl. Budapest: BTE-IFAMKM, 185-206.

Lugosi, P., Bell, D. and Lugosi, K. 2010. Hospitality, Culture and Regeneration: Urban Decay, Entrepreneurship and the 'Ruin' Bars of Budapest. Urban Studies, 47 (14), 3079-3101.

Sailer-Fliege, U. 1999. Characteristics of Post-socialist Urban Transformation in East Central Europe. GeoJournal 49, 7-16.

Sýkora, L. and Bouzarovski, S. 2012. Multiple Transformations: Conceptualising the Post-communist Urban Transition. Urban Studies, 49 (1), 43-60.

Szabó, T., Gauder, P. and Albel, É. 2011. Budapest metropolisz strukturális átalakítása. Tér és Társadalom, 25 (1), 119-132.

Tomay, K. 2007. Városrehabilitáció és dzsentrifikáció. In G. Enyedi (ed.) 2007. A történelmi városközpontok átalakulásának társadalmi hatása. Budapest, MTA Társadalomkutató Központ, 119-149. 